\title{
Review
}

\section{Disability and political theory}

\author{
Barbara Arneil and Nancy Hirschmann (Eds.) \\ Cambridge, UK: Cambridge University Press, 2016, xv + 322pp. ISBN: \\ 978-1107165694
}

Contemporary Political Theory (2022) 21, S76-S79. https://doi.org/10.1057/s41296021-00493-x; published online 19 May 2021

Writing in 1985, Harlan Hahn observed that political scientists had 'failed to devote significant attention to disability', despite its prevalence and its significance for questions of domestic policy (Hahn, 1985, p. 87). Remarking on the potential transformative impact of disability studies on the discipline, Hahn - a professor of political science at the University of Southern California - invited his colleagues to explore the intersection of these two fields in greater depth. And yet, over thirtyfive years later, disability remains a largely neglected topic of disciplinary inquiry, a fact that is as much true for political theory as it is for political science as a whole. 'Political theorists', Deborah Stone puts it bluntly, 'have shunted disabled people aside with scarcely an intellectual hiccough' (p. xiv).

Barbara Arneil and Nancy Hirschmann's edited volume, Disability and Political Theory, offers a much-needed corrective to this state of affairs, highlighting that disability is not just relevant to political theory, but necessary for discerning the exclusionary - indeed, ableist - assumptions that undergird concepts like justice, freedom, and equality. Bringing these assumptions into view, it is incumbent upon political theorists, as Arneil and Hirschmann see it, to 'redefine citizenship and the foundational concepts within politics to be more inclusive of disabled identities' ( $p$. 3 ). Described as a 'clarion call and ... a catalyst to the discipline of political science and in particular the subfield of political theory', this pathbreaking volume stands as a powerful rejoinder to those who might otherwise dismiss disability as ancillary to politics and the concerns of political theorists (p. 5).

Loosely organized by topic and methodological orientation, the volume's eleven essays are exemplary of the many ways that political theorists might, as Arneil and Hirschmann put it, 'take up disability as a central concern of their analyses' (p. 2). The first four chapters consider the role of disability in the canon of political thought, both as it defines the boundaries of the putatively rational, autonomous citizen, and as a disruptive presence that challenges us to rethink concepts central to Enlightenment political thought. Responding to Arneil and Hirschmann's call to 'redefin[e] ... the principles of political theory' (p. 4), the subsequent five

(C) 2021 The Author(s), under exclusive licence to Springer Nature Limited. 1470-8914 Contemporary Political Theory Vol. 21, S2, S76-S79

www.palgrave.com/journals 
chapters suggest possible paths forward, showing how disability offers a novel perspective on contemporary social and political problems, from the so-called anxiety 'epidemic' among women and girls (Eileen Hunt Botting's 'The Rationality of Women's Anxiety') to the treatment of dyslexia (Kathy Ferguson's 'Dyslexia Manifesto'). The final two chapters strike a slightly different tone, taking up contemporary issues and debates within the disabled community - specifically, violence against disabled people (Joan Tronto's 'Disability and Violence: Another Call for Democratic Inclusion and Pluralism') and the political and ethical dilemmas raised by the drive to cure disability (Nancy Hirschmann and Rogers Smith's 'Rethinking Cure and Accommodation'). Because of the breadth and scope of the volume, for the purposes of this review, I will focus my comments on three chapters that speak to the volume's strengths and suggest areas for further development before offering some brief reflections on the volume as a whole.

Building on arguments developed in her recent book, The Capacity Contract: Intellectual Disability and the Question of Citizenship (2015), Stacy Clifford Simplican's 'Disavowals of Disability in Rawls' Theory of Justice and his Critics' uncovers the 'disabling assumptions' built into Rawls's theory - assumptions that perpetuate the very systems of inequality Rawls seems so concerned to address (p. 85). Where previous scholarship has focused on Rawls's explicit exclusion of people with severe cognitive disabilities in Political Liberalism, Clifford Simplican uncovers what she refers to as Rawls's 'double disavowal of disability' (p. 80): his decision to 'put aside' disability in Political Liberalism obscuring the role disability plays in setting the outer bounds of the 'normal' capacities assumed of the parties to the original contract (p. 81). This is fascinating work. Nevertheless, I wish Clifford Simplican had explored its implications in more detail. Rawls's idealization of the 'normal', rational individual has long been a target of criticism by feminist theorists, critical race theorists, and philosophers of disability alike. What does this more focused attention to differences of ability and capacity add to previous critiques? Clifford Simplican suggests that Rawls's disavowal of disability is in part a response to the 'pity and anxiety' it provokes - emotions thought to jeopardize the impartiality demanded of the parties to the original contract - but this seems to downplay the challenge disability poses for his theory (Rawls, 1971, p. 84). Indeed, the problem is not simply that disability is presumed to 'erode[] the well-being of non-disabled individuals and liberal society' (p. 91). Rather, disability seems to threaten its very foundations, the perceived nonreciprocal needs of disabled individuals standing at odds with a resourcist framework in which society is imagined as 'a cooperative venture for mutual advantage' (Rawls, 1971, p. 4).

Where Clifford Simplican highlights the exclusionary ground of Rawls's theory, Eileen Hunt Botting's 'Wollstonecraft, Hobbes, and the Rationality of Women's Anxiety' looks instead to the resources that might be found within the canon of political thought for reshaping how we think about disability in the present.

(C) 2021 The Author(s), under exclusive licence to Springer Nature Limited. 1470-8914 Contemporary $\quad$ S77 Political Theory Vol. 21, S2, S76-S79 
Turning to the 'epidemic' of anxiety among women, she makes a powerful case for understanding women's anxiety both as a 'response to unfavorable social conditions', and as a 'means for anticipating, critically assessing, and navigating the gender-inflected difficulties of life' (p. 127). One of the strongest contributions to the volume, this essay will also be of interest to disability studies scholars who have drawn attention to potential benefits - as opposed to the limitations - of disability. Where this work can at times seem frustratingly detached from social reality, Hunt Botting maintains an admirable balance between highlighting the strategic and even 'skillful' aspects of anxiety while still attending to its oftendebilitating effects (p. 128). For political theorists, her careful readings of Hobbes and Wollstonecraft offer an example of how disability might be brought into conversation with classical texts while still remaining attentive to their broader exclusionary assumptions.

Echoing Hunt Botting's concern that efforts at revaluation too often elide the potentially painful or debilitating aspects of disability, Nancy Hirschmann and Rogers Smith's 'Rethinking "Cure" and "Accommodation", addresses the tension between the desire to cure or even eradicate disability and demands for its accommodation. Rather than coming down on one side of this debate, they instead chart a middle course, rethinking cure not as "a "return", to some prior "normal" condition but rather a form of care that serves the best interests of the individual' (p. 284). This alternative is intriguing, but I am not convinced it answers to the problems presented by the belief that disability is an intrinsically negative condition' (p. 265). Specifically, the emphasis on individual interests strikes me as insufficient in the face of what, following Alison Kafer, we might think of as a 'curative imaginary' that pervades social and medical approaches to disability (Kafer, 2013, p. 27). Where Hirschmann and Smith seek to trouble the opposition between cure and accommodation, we might instead question the very terms of this debate. In offering this alternative, I am inspired by recent work in disability studies that seeks to move beyond the accommodationist model to imagine 'practices of accessibility' that, as Aimi Hamraie puts it, 'understand accessibility as a collective or societal imperative' rather than a response to an individual demand (Hamraie, 2016, p. 264).

Considering the volume as a whole, two aspects deserve further comment. The first is the decision to solicit contributions from both junior and senior scholars. Offering a space for established scholars to explore how disability speaks to - or even challenges - their intellectual commitments, Arneil and Hirschmann provide a model for how to encourage broader engagement with newer areas of inquiry. However, this also means that some of the contributions show an uneven grasp of the existing literature and debates in disability studies. Insofar as the volume is primarily aimed at political theorists, this is less problematic. But it risks rendering its insights less useful to scholars of disability studies, which is unfortunate. Second is the absence of any sustained engagement with the intersection between disability 
and race. To their credit, Arneil and Hirschmann acknowledge this oversight in their introduction, but I worry that this too easily perpetuates a similar neglect within disability studies, one that the field has only recently begun to address. Indeed, to the extent that political theorists offer 'a complex understanding of politics and the workings of power', they would seem uniquely poised to contribute to this debate (p. 4).

These concerns notwithstanding, Disability and Political Theory makes a powerful case for why political theorists of various stripes ought to concern themselves with disability. At once accessible and illuminating, the volume has something to offer both scholars already well-versed in disability studies and those without previous exposure to the field.

\section{References}

Clifford Simplican, S. (2015) The Capacity Contract: Intellectual Disability and the Question of Citizenship. Minneapolis, MN: University of Minnesota Press.

Hahn, H. (1985) Toward a politics of disability: Definitions, disciplines, and policies. Social Science Journal 22(4): 87-105.

Hamraie, A. (2016) Beyond accommodation: Disability, feminist philosophy, and the design of everyday academic life. PhiloSOPHIA 6(2): 259-271.

Kafer, A. (2013) Feminist, Queer, Crip. Bloomington, IN: Indiana University Press.

Rawls, J. (1971) A Theory of Justice. Cambridge, MA: Belknap Press of Harvard University Press.

Publisher's Note Springer Nature remains neutral with regard to jurisdictional claims in published maps and institutional affiliations.

Ann K. Heffernan

University of Michigan, Ann Arbor, MI 48109, USA

akheff@umich.edu 